\title{
Education for Sustainable Development: Glocal Implications for Universities
}

\author{
Lilia Raitskaya ${ }^{1}$, Elena Tikhonova ${ }^{2,3}$ \\ ${ }^{1}$ Moscow State Institute of International Relations (MGIMO University) \\ ${ }^{2}$ National Research University Higher School of Economics \\ ${ }^{3}$ Peoples' Friendship University of Russia (RUDN University)
}

\begin{abstract}
Correspondence concerning this article should be addressed to Elena Tikhonova, National Research University Higher School of Economics, 11 Pokrovsky Bulvar, Pokrovka Complex, room S313, Moscow, 109028, Russian Federation. E-mail: etihonova@hse.ru
\end{abstract}

\begin{abstract}
The editorial overviews the key research aspects of embedding sustainable development into university systems worldwide. The JLE editors dwell upon the pivotal role of higher education in transferring knowledge, skills, and underlying values in promoting Sustainable Development Goal No.4 (Quality Education for Sustainable Development). The editorial analysis is underpinned by the most cited Scopus-indexed articles (Top-50 as of March 2021) on sustainable development in higher education. JLE potential authors will find some recommendations on the subject field gaps and key directions to be published in the journal upcoming issues.
\end{abstract}

Keywords: sustainable development, sustainability, higher education, competencies, curriculum, teaching and learning environment, glocality

\section{Introduction}

Sustainability entered the global agenda in the 1970s with the UN Commission on Environment and Development report headlined "Our Common Future"1. The latter defined sustainable development as the process meeting "the needs of the present without compromising the ability of future generations to meet their own needs"2.

The Millennium Development Goals (MDGs) were adopted in 2000. The eight goals were to be attained by 2015 . All the UN member states committed to support the MDGs. Goal Two had universal primary education, including enrolment and completion for boys and girls, as its key target. In 2015, the UN Resolution headlined “Transforming Our World: the 2030 Agenda for Sustainable Development" (widely known as Agenda 2030) was passed. It set forth seventeen Sustainable Development Goals (SDGs). The goals were worded quite broadly to cover the global vital needs in economic, social, and environmental spheres. A special system of targets and indicators was developed to monitor the progress towards the SDGs.

Goal 4 - Quality Education - provides for "inclusive and equitable education" and "lifelong learning opportunities" for all ${ }^{3}$. Education for Sustainable Development (ESD) encompasses "economic, social and environmental dimensions of the formal and informal curricula" ${ }^{4}$. Though much of ESD is focused on primary and secondary education, the role of higher education is being reconsidered and highly appreciated. Since 2015, sustainable development and sustainability have been thoroughly discussed across economic, social, political, and environmental strata. The sustainability concepts were transformed into numerous practical models. At present, the prevailing view sticks to the three pillars of sustainable development, with education considered as raising awareness, generating transformation in mindsets. It 'aims to facilitate the development of skills to contribute to a more sustainable future” (Avila et al., 2018, p. 109). They all are addressed at both global and local levels, resulting in the glocality of the sustainable development as a phenomenon

Education is relevant to the other SDGs, as it prepares young people to live and work in the environment heavily relied on sustainable development principles, including the key competencies relating to SD (Systems

\footnotetext{
1 Report of the World Commission on Environment and development: Our common future. https://sustainabledevelopment.un.org/content/documents/5987our-common-future.pdf

2 World Commission on Environment and Development (WCED). (1991). Our common future (2nd ed.). Rio de Getúlio Vargas Foundation. P. 42.

3 4: Quality Education. http://www.undp.org/content/undp/en/home/sustainable-development-goals/goal-4-quality-education.html

4 Advance HE. Education for Sustainable Development. https://www.advance-he.ac.uk/knowledge-hub/education-sustainable-development-0
} 
thinking, Anticipatory, Normative, Strategic, Collaboration, Critical thinking, Self-Awareness, and Integrated problem-solving) ${ }^{5}$.

As the JLE scope in education is mainly limited to higher education, we aim to scrutinize the prevailing research trends in the field of higher education for sustainable development. To complete the task, a review of the most cited articles indexed with the Scopus database was carried out to single out the top 50 most cited publications between 2015 (the adoption of Agenda 2030) and 2020. Thus, the research question in the review can be confined to the following: What are the prevailing trends within the field of higher education for sustainable development?

\section{Materials and Methods}

\section{Rationale for the Review Criteria}

To estimate the hot topics and find out the prevailing trends in the field of higher education for sustainable development, we focused of the publications indexed with the Scopus database. The Scopus database was selected as it covers the most influential sources on Sustainable Development. The search within the base brought authoritative results (publications with citations in high-ranking journals).

As Agenda 2030 was adopted in 2015, the review period spans from 2015 to 2020. The following inclusion/ exclusion criteria were fixed to filter the publications (see Table 1).

Table 1

Review Inclusion and Exclusion Criteria

\begin{tabular}{lll}
\hline \multicolumn{1}{c}{ Criteria } & \multicolumn{1}{c}{ Inclusion } & \multicolumn{1}{c}{ Exclusion } \\
\hline Time Span & $2015-2020$ & Beyond the stated period \\
Document Type & Article & All other types, but for articles \\
Keywords & Education for sustainable development & All other keywords \\
& Higher education for sustainable development & \\
& Higher education institutions (HEIs) & \\
& Sustainable development goals (SDGs) & \\
& Education policy & \\
& Lifelong learning & \\
Research Area & Social Sciences & Sciences and research fields beyond social \\
& English & Sciences \\
Languages & & Other languages \\
\hline
\end{tabular}

The 50 most highly cited articles on higher education for sustainable development were sifted. The complete list forms Appendix 1 (See Appendix A).

\section{Procedure}

The initial search with "education for sustainable development" in the field covering titles, abstracts and keywords in the Scopus database, accessed March 1, 2021 and evaluated on the basis of the keyword inclusion criteria brought 24,177 documents. 10,223 indexed publications belonged to Social Sciences, partly overlapped by 1,234 in Economics, Econometrics and Finance, and 6,197 in Environmental Science. The search results were refined through the inclusion criteria. Then we singled out the first 50 most highly cited articles, with the article headlined "Connecting competences and pedagogical approaches for sustainable development in higher education: A literature review and framework proposal" (Lozano, Merrill, Sammalisto, Ceulemans, \& Lozano, 2017) topping the search. The highest citation among the reviewed publications was recorded as high as 127 as of March 15, 2021. The lowest citation in the list reached 18. It was "Neoliberalism, pluralism and environmental education: The call for radical re-orientation” (Kopnina, 2015).

\footnotetext{
5 UNESCO. 2017. Education for sustainable development goals learning objectives. United Nations Educational, Scientific and Cultural Organization. https://www.unesco.de/sites/default/files/2018-08/unesco_education_for_sustainable_development_goals.pdf
} 
The bibliometric analysis of the 50 documents showed that the selected publications were distributed unevenly, with 14 in 2015; 8 in 2016; 11 in 2017; 9 in 2018; 8 in 2019. No publication reached comparatively high readings in 2020. The articles came out in the following sources: Sustainability (Switzerland) - 14 articles; Environmental Education Research - 9 articles; International Journal of Management - 3 articles; another three journals with two publications each; eleven journals with one article each.

The research area was limited to social sciences ( $\mathrm{n}=50,100 \%)$, though some of the articles in the review have more than one subject area: social science \& environmental science $(n=21)$; social science \& energy $(n=14)$; social sciences \& business, management and accounting $(n=4)$; social sciences \& economics, econometrics and finance $(n=4)$; social sciences \& agricultural and biological sciences $(n=1)$; social sciences \& engineering $(n=1)$; social sciences \& mathematics $(n=1)$. The most prolific authors in Top-50 are Gericke, N. (4 articles); Kopnina, H. (3 articles); Lozano, R. (3 articles); Olsson, D. (3 articles); Sammalisto, K. (3 articles).

\section{Figure 1}

Scopus Indexed Research on Higher Education for Sustainable Development (Social Sciences): Affiliation Breakdown. Source: Scopus Database as of March 1, 2021

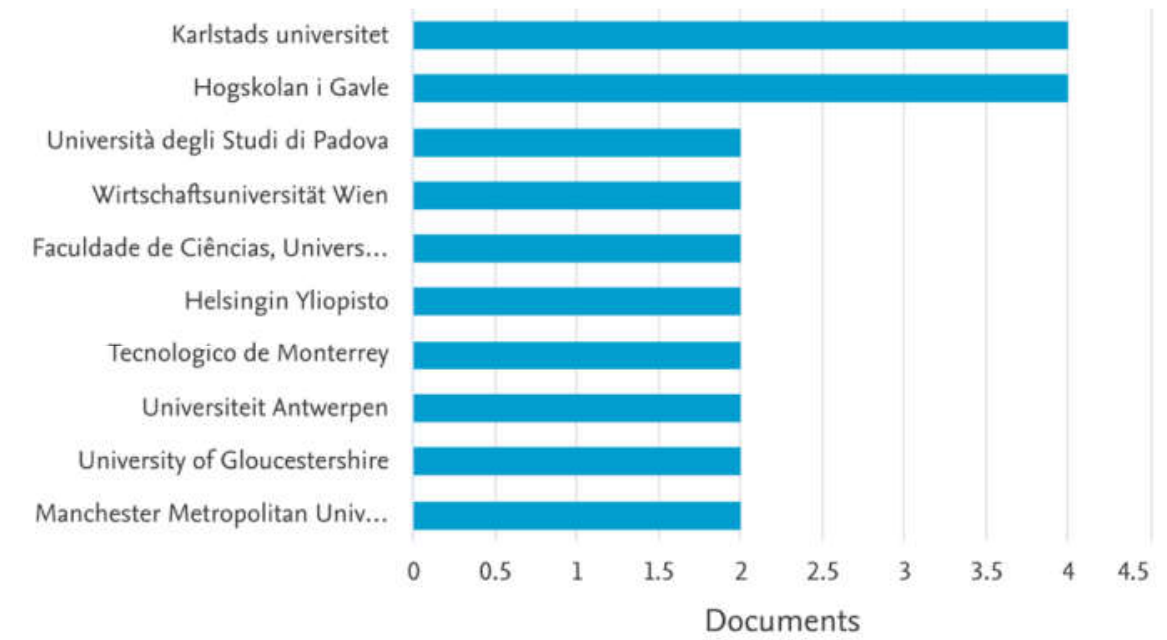

Two universities were affiliation leaders, with four articles each (See Figure 1). They are Karlstads universitet and Högskolan i Gävle. Both are located in Sweden. As for the aggregate number of the articles in the top list, the highest scores belong to the UK (15 articles) and Sweden (11 articles) by a large margin (See Figure 2).

\section{Figure 2}

Scopus Indexed Research on Higher Education for Sustainable Development (Social Sciences): Leading Countries. Source: Scopus Database as of March 1, 2021

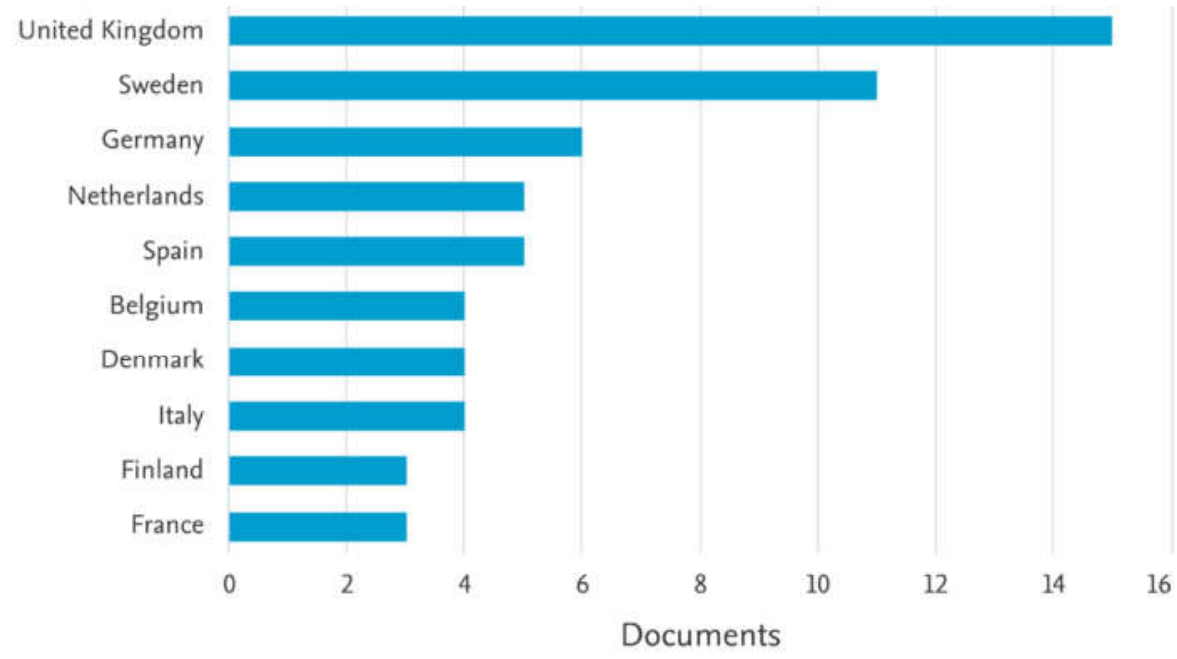




\section{Results and Discussion}

The thematic clusters within the field of higher education for sustainable development boiled down to eight: general issues of ESD; country-specific experiences; higher professional education; skills and competencies; attitudes and perceptions; assessment; curriculum; neoliberal aspects and ESD (See Table 2). The breakdown of the articles does not exclude their overlapping when their topic is complex.

Table 2

Thematic Clusters within the Field of Higher Education for Sustainable Development

\begin{tabular}{|c|c|c|}
\hline Thematic Cluster & $\begin{array}{c}\text { Number of } \\
\text { Publications in Top } 50\end{array}$ & Cluster Description \\
\hline General issues of ESD & 10 & $\begin{array}{l}\text { Mechanisms of planning and implementing the SDGs, future prospects and } \\
\text { expectations, effectiveness of SDG programmes, a framework for connecting } \\
\text { the SDGs to educational outcomes, professional development initiatives for } \\
\text { university educators to address the SD challenges }\end{array}$ \\
\hline Country-specific experiences & 8 & $\begin{array}{l}\text { The research of cases specific of a particular country (Portugal, Sweden, } \\
\text { Canada, Malaysia, Italy, Germany, Spain, UK) }\end{array}$ \\
\hline $\begin{array}{l}\text { Higher professional } \\
\text { education }\end{array}$ & 8 & $\begin{array}{l}\text { This cluster covers specialized education (teacher education, engineering, } \\
\text { science and environmental education, management education) in its efforts } \\
\text { to promote sustainable development, incorporate the SD principles in their } \\
\text { curriculum and learning/ teaching across disciplines }\end{array}$ \\
\hline Skills and competencies & 9 & $\begin{array}{l}\text { Pedagogical approaches in designing and delivering sustainability- } \\
\text { oriented competencies, connections between pedagogical approaches and } \\
\text { development of sustainability competencies, transformative learning }\end{array}$ \\
\hline Attitudes and perceptions & 8 & $\begin{array}{l}\text { Practical approaches to advancing education for sustainable development, } \\
\text { hope and anticipation relating to ESD }\end{array}$ \\
\hline Assessment & 6 & $\begin{array}{l}\text { Assessment tools within the sustainability framework, assessment indicators } \\
\text { to measure, audit, and benchmark efforts at embedding SD }\end{array}$ \\
\hline Curriculum & 5 & Approaches and hurdles of SD integration into a university curriculum \\
\hline Neoliberal aspects and ESD & 3 & The threat of neoliberal values to sustainability models in education \\
\hline
\end{tabular}

\section{General Issues of ESD}

Though Agenda 2030 was adopted over five years ago, there are still many research articles on the ESD foundations, on the ways the SD principles are incorporated into higher education systems. Researchers study the SD perspectives for higher education (Filho, Manolas \& Pace, 2015; Sonetti, Brown \& Naboni, 2019), sustainable educational policy (Van Poeck \& Lysgaard, 2016); coherence between theory and praxis of ESD (Amador, Martinho, Bacelar-Nicolau, Caeiro \& Oliveira, 2015); professional development initiatives for educators to efficiently embed SD into higher education (Mulà et al., 2017).

\section{Country-Specific Experiences}

As all UN member states are committed to Agenda 2030, each has its own experience in ESD. Top-50 encompasses several country-specific publications. They focus on the ESD implementation progress in Portugal (Aleixo, Azeiteiro \& Leal, 2018); gender-related aspects of students' sustainability consciousness in Sweden (Olsson \& Gericke, 2017); the national higher education sustainability policies in Canada (Lidstone, Wright \& Sherren, 2015), a quantitative SD scale at an Italian university (Biasutti \& Frate, 2017), etc.

\section{Higher Professional Education}

$\mathrm{SD}$ is relevant to most of spheres of human activities. But some professions are at the forefront, having more relevance and responsibility. Thus, teacher education (Álvarez-García, Sureda-Negre \& Comas-Forgas, 2015), engineering education (Guerra, 2017), science (Eilks, 2015) and environmental education (Kopnina, 2015) can 
promote SD not only within their segment of education, but via their graduates widely spread the SD values across their professional communities.

\section{Skills and Competencies}

The research on skills and competencies have been in focus since SDG No.4 is in place. In 2017, special skills were set forth as vital in attaining the SDGs (UNESCO). As a result, much attention is paid to studies on the pedagogical design and delivery of sustainability-oriented competencies (Lozano, Barreiro-Gen, Lozano \& Sammalisto, 2019; Lozano, Merrill, Sammalisto, Ceulemans \& Lozano, 2017; Cebrián \& Junyent, 2015), critical thinking (Straková \& Cimermanová, 2018; Hasslöf \& Malmberg, 2015), and systems thinking (Waltner, Rieß \& Mischo, 2019). Though many publications on competencies come out annually, the considered papers focus on the competencies that must transform the mindsets of the younger generations to efficiently address the sustainability challenges.

\section{Attitudes and Perceptions}

Some of the articles in this cluster enter into the other clusters, too. The publications highlight students', teachers', and educators' perceptions of sustainable development, attitudes to pedagogical approaches to fostering skills and competencies, hope and anticipation in ESD (Ojala, 2017; Berglund \& Gericke, 2016; Olsson \& Gericke, 2016).

\section{Assessment}

Assessment arose as separate sub-field in response to the pressing need to monitor SD implementation, including attaining targets within Goal 4. Indicators are being worked out to gauge the progress. The articles in this cluster encompass studies of sustainability assessment tools (Fischer, Jenssen \& Tappeser, 2015); assessment of the impacts of higher education institutions on sustainable development (Findler, Schönherr, Lozano \& Stacherl, 2018); assessment of sustainability literacy (Décamps, Barbat, Carteron, Hands \& Parkes, 2017), etc.

\section{Curriculum}

Embedding SD into university curricula implies an all-round system of the SD implementation. The studies concentrate on curriculum change (Kolmos, Hadgraft \& Holgaard, 2016), the project method in integrating SD into higher education curricula (Fuertes-Camacho, Graell-Martín, Fuentes-Loss \& Balaguer-Fàbregas, 2019); SD curricula in degree programmes (Wyness \& Sterling, 2015). Curricula change algorithm is not universal, as in some countries there are institutional hurdles. Curricula cannot easily be changed.

\section{Neoliberal Aspects and ES}

The neoliberal values are in contrast with the SD principles. Higher education in many countries is inclined to neoliberal philosophy. Students may absorb controversial sets of values. Thus, their commitment to SD may be considerable distorted (Kopnina \& Cherniak, 2016; Kopnina, 2015).

\section{Conclusion}

The review analysis displays the eight key research trends in the subject area of ESD: general issues of ESD; country-specific experiences; higher professional education; skills and competencies; attitudes and perceptions; assessment; curriculum; neoliberal aspects and ESD, with a greater focus on all aspects of practical models of ESD across countries and sciences. The reviewed publications prove that all trends emerge and evolve glocally.

With its commitment to tertiary education, the JLE is going to bring out more articles and reviews in the light of the SDGs and ESD. Research on pedagogical approaches to efficient fostering skills and competencies for sustainability is certain to be prioritised. Studies of glocal models of imbedding sustainability in university curriculum and academic systems at large will also be highly appreciated. 


\section{References}

Aleixo, A. M., Azeiteiro, U., \& Leal, S. (2018). The implementation of sustainability practices in Portuguese higher education institutions. International Journal of Sustainability in Higher Education, 19(1), 146-178. https://doi. org/10.1108/IJSHE-02-2017-0016

Álvarez-García, O., Sureda-Negre, J., \& Comas-Forgas, R. (2015). Environmental education in pre-service teacher training: A literature review of existing evidence. Journal of Teacher Education for Sustainability, 17(1), 72-85. https://doi.org/10.1515/jtes-2015-0006

Amador, F., Martinho, A. P., Bacelar-Nicolau, P., Caeiro, S., \& Oliveira, C. P. (2015). Education for sustainable development in higher education: Evaluating coherence between theory and praxis. Assessment and Evaluation in Higher Education, 40(6), 867-882. https://doi.org/10.1080/02602938.2015.1054783

Avila, V.L., Facco, A.L.R., Bento, M.H.S., Arigony, M.M., Obregon, S.L., \& Trevisan, M. (2018). Sustainability and Education for Sustainability: An Analysis of Publications from the Last Decade. Environmental Quality Management, 27, 107-118. https://doi.org/10.1002/tqem.21537

Berglund, T., \& Gericke, N. (2016). Separated and integrated perspectives on environmental, economic, and social dimensions - an investigation of student views on sustainable development. Environmental Education Research, 22(8), 1115-1138. https://doi.org/10.1080/13504622.2015.1063589

Biasutti, M., \& Frate, S. (2017). A validity and reliability study of the attitudes toward sustainable development scale. Environmental Education Research, 23(2), 214-230. https://doi.org/10.1080/13504622.2016.1146660

Cebrián, G., \& Junyent, M. (2015). Competencies in education for sustainable development: Exploring the student teachers' views. Sustainability, 7(3), 2768-2786. https://doi.org/10.3390/su7032768

Décamps, A., Barbat, G., Carteron, J., Hands, V., \& Parkes, C. (2017). Sulitest: A collaborative initiative to support and assess sustainability literacy in higher education. International Journal of Management Education, 15(2), 138-152. https://doi.org/10.1016/j.ijme.2017.02.006

Eilks, I. (2015). Science education and education for sustainable development - justifications, models, practices and perspectives. Eurasia Journal of Mathematics, Science and Technology Education, 11(1), 149-158. https:// doi.org/10.12973/eurasia.2015.1313a

Filho, W. L., Manolas, E., \& Pace, P. (2015). The future we want key issues on sustainable development in higher education after Rio and the un decade of education for sustainable development. International Journal of Sustainability in Higher Education, 16(1), 112-129. https://doi.org/10.1108/IJSHE-03-2014-0036

Findler, F., Schönherr, N., Lozano, R., \& Stacherl, B. (2018). Assessing the impacts of higher education institutions on sustainable development-an analysis of tools and indicators. Sustainability, 11(1), 59. https:// doi.org/10.3390/su11010059

Fuertes-Camacho, M. T., Graell-Martín, M., Fuentes-Loss, M., \& Balaguer-Fàbregas, M. C. (2019). Integrating sustainability into higher education curricula through the project method, a global learning strategy. Sustainability, 11(3), 767. https://doi.org/10.3390/su11030767

Guerra, A. (2017). Integration of sustainability in engineering education: Why is PBL an answer? International Journal of Sustainability in Higher Education, 18(3), 436-454. https://doi.org/10.1108/IJSHE-02-2016-0022

Hasslöf, H., \& Malmberg, C. (2015). Critical thinking as room for subjectification in education for sustainable development. Environmental Education Research, 21(2), 239-255. https://doi.org/10.1080/13504622.2014.940854

Kolmos, A., Hadgraft, R. G., \& Holgaard, J. E. (2016). Response strategies for curriculum change in engineering. International Journal of Technology and Design Education, 26(3), 391-411. https://doi.org/10.1007/ s10798-015-9319-y

Kopnina, H. (2015). Neoliberalism, pluralism and environmental education: The call for radical reorientation. Environmental Development, 15, 120-130. https://doi.org/10.1016/j.envdev.2015.03.005

Kopnina, H.(2015). Sustainability in environmental education: New strategic thinking. Environment, Development and Sustainability, 17(5), 987-1002. https://doi.org/10.1007/s10668-014-9584-z

Kopnina, H., \& Cherniak, B. (2016). Neoliberalism and justice in education for sustainable development: A call for inclusive pluralism. Environmental Education Research, 22(6), 827-841. https://doi.org/10.1080/13504622 .2016 .1149550

Lidstone, L., Wright, T., \& Sherren, K. (2015). An analysis of Canadian STARS-rated higher education sustainability policies. Environment, Development and Sustainability, 17(2), 259-278. https://doi.org/10.1007/ s10668-014-9598-6

Lozano, R., Barreiro-Gen, M., Lozano, F. J., \& Sammalisto, K. (2019). Teaching sustainability in European higher education institutions: Assessing the connections between competences and pedagogical approaches. Sustainability, 11(6), 1602. https://doi.org/10.3390/su11061602 
Lozano, R., Merrill, M. Y., Sammalisto, K., Ceulemans, K., \& Lozano, F. J. (2017). Connecting competences and pedagogical approaches for sustainable development in higher education: A literature review and framework proposal. Sustainability, 9(10), 1889. https://doi.org/10.3390/su9101889

Mulà, I., Tilbury, D., Ryan, A., Mader, M., Dlouhá, J., Mader, C., Benayas, J.,_louhý, J., Alba, D. (2017). Catalysing change in higher education for sustainable development: A review of professional development initiatives for university educators. International Journal of Sustainability in Higher Education, 18(5), 798-820. https://doi. org/10.1108/IJSHE-03-2017-0043

Ojala, M. (2017). Hope and anticipation in education for a sustainable future. Futures, 94, 76-84. https://doi. org/10.1016/j.futures.2016.10.004

Olsson, D., \& Gericke, N. (2016). The adolescent dip in students' sustainability consciousness - implications for education for sustainable development. Journal of Environmental Education, 47(1), 35-51. https://doi.org/10. 1080/00958964.2015.1075464

Olsson, D., \& Gericke, N. (2017). The effect of gender on students' sustainability consciousness: A nationwide Swedish study. Journal of Environmental Education, 48(5), 357-370. https://doi.org/https://doi.org/10.1080/0 0958964.2017.1310083

Sonetti, G., Brown, M., \& Naboni, E. (2019). About the triggering of UN sustainable development goals and regenerative sustainability in higher education. Sustainability, 11(1), 254.https://doi.org/10.3390/su11010254

Straková, Z., \& Cimermanová, I. (2018). Critical thinking development-a necessary step in higher education transformation towards sustainability. Sustainability (Switzerland), 10(10). https://doi.org/10.3390/ su10103366

Van Poeck, K., \& Lysgaard, J. A. (2016). The roots and routes of environmental and sustainability education policy research. Environmental Education Research, 22(3), 305-318. https://doi.org/10.1080/13504622.2015. 1108393

Waltner, E., Rieß, W., \& Mischo, C. (2019). Development and validation of an instrument for measuring student sustainability competencies. Sustainability (Switzerland), 11(6). https://doi.org/10.3390/su11061717

Wyness, L., \& Sterling, S. (2015). Reviewing the incidence and status of sustainability in degree programmes at Plymouth university. International Journal of Sustainability in Higher Education, 16(2), 237-250. https://doi. org/10.1108/IJSHE-09-2013-0112 


\section{Appendix A}

\section{Top-50 Highly Cited Articles on Higher Education for Sustainable Development}

Albareda-Tiana, S., Vidal-Raméntol, S., \& Fernández-Morilla, M. (2018). Implementing the sustainable development goals at university level. International Journal of Sustainability in Higher Education, 19(3), 473497. https://doi.org/10.1108/IJSHE-05-2017-0069

Aleixo, A. M., Azeiteiro, U., \& Leal, S. (2018). The implementation of sustainability practices in Portuguese higher education institutions. International Journal of Sustainability in Higher Education, 19(1), 146-178. https://doi. org/10.1108/IJSHE-02-2017-0016

Álvarez-García, O., Sureda-Negre, J., \& Comas-Forgas, R. (2015). Environmental education in pre-service teacher training: A literature review of existing evidence. Journal of Teacher Education for Sustainability, 17(1), 72-85. https://doi.org/10.1515/jtes-2015-0006

Amador, F., Martinho, A. P., Bacelar-Nicolau, P., Caeiro, S., \& Oliveira, C. P. (2015). Education for sustainable development in higher education: Evaluating coherence between theory and praxis. Assessment and Evaluation in Higher Education, 40(6), 867-882. doi:10.1080/02602938.2015.1054783

Annan-Diab, F., \& Molinari, C. (2017). Interdisciplinarity: Practical approach to advancing education for sustainability and for the sustainable development goals. International Journal of Management Education, 15(2), 73-83. https://doi.org/10.1016/j.ijme.2017.03.006

Berglund, T., \& Gericke, N. (2016). Separated and integrated perspectives on environmental, economic, and social dimensions - an investigation of student views on sustainable development. Environmental Education Research, 22(8), 1115-1138. https://doi.org/10.1080/13504622.2015.1063589

Bessant, S. E. F., Robinson, Z. P., \& Ormerod, R. M. (2015). Neoliberalism, new public management and the sustainable development agenda of higher education: History, contradictions and synergies. Environmental Education Research, 21(3), 417-432. https://doi.org/10.1080/13504622.2014.993933

Biasutti, M. (2015). An intensive programme on education for sustainable development: The participants' experience. Environmental Education Research, 21(5), 734-752. https://doi.org/10.1080/13504622.2014.921805

Biasutti, M., \& Frate, S. (2017). A validity and reliability study of the attitudes toward sustainable development scale. Environmental Education Research, 23(2), 214-230. https://doi.org/10.1080/13504622.2016.1146660

Borges, J. C., Ferreira, T. C., Borges de Oliveira, M. S., Macini, N., \& Caldana, A. C. F. (2017). Hidden curriculum in student organizations: Learning, practice, socialization and responsible management in a business school. International Journal of Management Education, 15(2), 153-161. https://doi.org/10.1016/j. ijme.2017.03.003

Cebrián, G., \& Junyent, M. (2015). Competencies in education for sustainable development: Exploring the student teachers' views. Sustainability (Switzerland), 7(3), 2768-2786. https://doi.org/10.3390/su7032768

Décamps, A., Barbat, G., Carteron, J., Hands, V., \& Parkes, C. (2017). Sulitest: A collaborative initiative to support and assess sustainability literacy in higher education. International Journal of Management Education, 15(2), 138-152. https://doi.org/10.1016/j.ijme.2017.02.006

Eilks, I. (2015). Science education and education for sustainable development - justifications, models, practices and perspectives. Eurasia Journal of Mathematics, Science and Technology Education, 11(1), 149-158. https:// doi.org/10.12973/eurasia.2015.1313a

Filho, W. L., Manolas, E., \& Pace, P. (2015). The future we want key issues on sustainable development in higher education after Rio and the un decade of education for sustainable development. International Journal of Sustainability in Higher Education, 16(1), 112-129. https://doi.org/10.1108/IJSHE-03-2014-0036

Findler, F., Schönherr, N., Lozano, R., \& Stacherl, B. (2018). Assessing the impacts of higher education institutions on sustainable development-an analysis of tools and indicators. Sustainability, 11(1), 59. https:// doi.org/10.3390/su11010059

Fischer, D., Jenssen, S., \& Tappeser, V. (2015). Getting an empirical hold of the sustainable university: A comparative analysis of evaluation frameworks across 12 contemporary sustainability assessment tools. Assessment and Evaluation in Higher Education, 40(6), 785-800. https://doi.org/10.1080/02602938.2015.1043234

Fuertes-Camacho, M. T., Graell-Martín, M., Fuentes-Loss, M., \& Balaguer-Fàbregas, M. C. (2019). Integrating sustainability into higher education curricula through the project method, a global learning strategy. Sustainability, 11(3), 767. https://doi.org/10.3390/su11030767

Giangrande, N., White, R. M., East, M., Jackson, R., Clarke, T., Coste, M. S., \& Penha-Lopes, G. (2019). A competency framework to assess and activate education for sustainable development: Addressing the UN sustainable development goals 4.7 challenge. Sustainability, 11(10), 2832. https://doi.org/10.3390/su11102832 
Guerra, A. (2017). Integration of sustainability in engineering education: Why is PBL an answer? International Journal of Sustainability in Higher Education, 18(3), 436-454. https://doi.org/10.1108/IJSHE-02-2016-0022

Hartley, B. L., Pahl, S., Holland, M., Alampei, I., Veiga, J. M., \& Thompson, R. C. (2018). Turning the tide on trash: Empowering european educators and school students to tackle marine litter. Marine Policy, 96, 227234. https://doi.org/10.1016/j.marpol.2018.02.002

Hasslöf, H., \& Malmberg, C. (2015). Critical thinking as room for subjectification in education for sustainable development. Environmental Education Research, 21(2), 239-255. https://doi.org/10.1080/13504622.2014.94 0854

Hoffmann, R., \& Muttarak, R. (2017). Learn from the past, prepare for the future: Impacts of education and experience on disaster preparedness in the philippines and thailand. World Development, 96, 32-51. https:// doi.org/10.1016/j.worlddev.2017.02.016

Kioupi, V., \& Voulvoulis, N. (2019). Education for sustainable development: A systemic framework for connecting the SDGs to educational outcomes. Sustainability, 11(21), 6104. https://doi.org/10.3390/su11216104

Kolmos, A., Hadgraft, R. G., \& Holgaard, J. E. (2016). Response strategies for curriculum change in engineering. International Journal of Technology and Design Education, 26(3), 391-411. https://doi.org/10.1007/ s10798-015-9319-y

Kopnina, H. (2015). Neoliberalism, pluralism and environmental education: The call for radical reorientation. Environmental Development, 15, 120-130. https://doi.org/10.1016/j.envdev.2015.03.005

Kopnina, H. (2015). Sustainability in environmental education: New strategic thinking. Environment, Development and Sustainability, 17(5), 987-1002. https://doi.org/10.1007/s10668-014-9584-z

Kopnina, H., \& Cherniak, B. (2016). Neoliberalism and justice in education for sustainable development: A call for inclusive pluralism. Environmental Education Research, 22(6), 827-841. https://doi.org/10.1080/13504622 .2016 .1149550

Lambrechts, W., \& Van Petegem, P. (2016). The interrelations between competences for sustainable development and research competences. International Journal of Sustainability in Higher Education, 17(6), 776-795. https:// doi.org/10.1108/IJSHE-03-2015-0060

Leal Filho, W., Pallant, E., Enete, A., Richter, B., \& Brandli, L. L. (2018). Planning and implementing sustainability in higher education institutions: An overview of the difficulties and potentials. International Journal of Sustainable Development and World Ecology, 25(8), 712-720. https://doi.org/10.1080/13504509.2018.1461707

$\mathrm{Li}, \mathrm{C}$, \& Zhou, H. (2018). Enhancing the efficiency of massive online learning by integrating intelligent analysis into MOOCs with an application to education of sustainability. Sustainability, 10(2), 468. https://doi. org/10.3390/su10020468

Lidstone, L., Wright, T., \& Sherren, K. (2015). An analysis of Canadian STARS-rated higher education sustainability policies. Environment, Development and Sustainability, 17(2), 259-278. https://doi.org/10.1007/ s10668-014-9598-6

Lozano, R., Barreiro-Gen, M., Lozano, F. J., \& Sammalisto, K. (2019). Teaching sustainability in European higher education institutions: Assessing the connections between competences and pedagogical approaches. Sustainability, 11(6), 1602. https://doi.org/10.3390/su11061602

Lozano, R., Merrill, M. Y., Sammalisto, K., Ceulemans, K., \& Lozano, F. J. (2017). Connecting competences and pedagogical approaches for sustainable development in higher education: A literature review and framework proposal. Sustainability, 9(10), 1889. https://doi.org/10.3390/su9101889

Mulà, I., Tilbury, D., Ryan, A., Mader, M., Dlouhá, J., Mader, C., Benayas, J., Dlouhý, J., Alba, D. (2017). Catalysing change in higher education for sustainable development: A review of professional development initiatives for university educators. International Journal of Sustainability in Higher Education, 18(5), 798-820. https://doi. org/10.1108/IJSHE-03-2017-0043

O'Flaherty, J., \& Liddy, M. (2018). The impact of development education and education for sustainable development interventions: A synthesis of the research. Environmental Education Research, 24(7), 1031-1049. https://doi.org/10.1080/13504622.2017.1392484

Ojala, M. (2017). Hope and anticipation in education for a sustainable future. Futures, 94, 76-84. https://doi. org/10.1016/j.futures.2016.10.004

Olsson, D., \& Gericke, N. (2016). The adolescent dip in students' sustainability consciousness - implications for education for sustainable development. Journal of Environmental Education, 47(1), 35-51. https://doi.org/10. 1080/00958964.2015.1075464

Olsson, D., \& Gericke, N. (2017). The effect of gender on students' sustainability consciousness: A nationwide Swedish study. Journal of Environmental Education, 48(5), 357-370. https://doi.org/10.1080/00958964.2017.1 310083 
Pauw, J. B., Gericke, N., Olsson, D., \& Berglund, T. (2015). The effectiveness of education for sustainable development. Sustainability, 7(11), 15693-15717. https://doi.org/10.3390/su71115693

Pihkala, P. (2017). Environmental education after sustainability: Hope in the midst of tragedy. Global Discourse, 7(1), 109-127. https://doi.org/10.1080/23269995.2017.1300412

Sammalisto, K., Sundström, A., Von Haartman, R., Holm, T., \& Yao, Z. (2016). Learning about sustainabilitywhat influences students' self-perceived sustainability actions after undergraduate education? Sustainability, 8(6), 510. https://doi.org/10.3390/su8060510

Schuler, S., Fanta, D., Rosenkraenzer, F., \& Riess, W. (2018). Systems thinking within the scope of education for sustainable development (ESD)-a heuristic competence model as a basis for (science) teacher education. Journal of Geography in Higher Education, 42(2), 192-204. https://doi.org/10.1080/03098265.201 7.1339264

Sonetti, G., Brown, M., \& Naboni, E. (2019). About the triggering of UN sustainable development goals and regenerative sustainability in higher education. Sustainability, 11(1), 254.https://doi.org/10.3390/su11010254

Straková, Z., \& Cimermanová, I. (2018). Critical thinking development-a necessary step in higher education transformation towards sustainability. Sustainability, 10(10), 3366. https://doi.org/10.3390/su10103366

Van Poeck, K., \& Lysgaard, J. A. (2016). The roots and routes of environmental and sustainability education policy research. Environmental Education Research, 22(3), 305-318. https://doi.org/10.1080/13504622.2015. 1108393

Vare, P., Arro, G., de Hamer, A., Gobbo, G. D., de Vries, G., Farioli, F., Kadji-Beltran, Ch., Kangur, M., Mayer, M., Millican, R., Nijdam, C., Réti, M., Zachariou, A. (2019). Devising a competence-based training program for educators of sustainable development: Lessons learned. Sustainability, 11(7), 1890. https://doi.org/10.3390/ su11071890

Vesterinen, V. -., Tolppanen, S., \& Aksela, M. (2016). Toward citizenship science education: What students do to make the world a better place? International Journal of Science Education, 38(1), 30-50. https://doi.org/10.10 80/09500693.2015.1125035

Waldron, F., Ruane, B., Oberman, R., \& Morris, S. (2019). Geographical process or global injustice? contrasting educational perspectives on climate change. Environmental Education Research, 25(6), 895-911. https://doi.or $\mathrm{g} / 10.1080 / 13504622.2016 .1255876$

Waltner, E., Rieß, W., \& Mischo, C. (2019). Development and validation of an instrument for measuring student sustainability competencies. Sustainability, 11(6), 1717. https://doi.org/10.3390/su11061717

Wyness, L., \& Sterling, S. (2015). Reviewing the incidence and status of sustainability in degree programmes at Plymouth university. International Journal of Sustainability in Higher Education, 16(2), 237-250. https://doi. org/10.1108/IJSHE-09-2013-0112 